\title{
THE COPYRIGHT AND PRIVACY NEXUS
}

\author{
Susy Frankel*
}

The New Zealand development of a tort limited to wrongful publication of private fact (and in the United Kingdom by extension of breach of confidence) has not been accompanied by a consideration of the relationship that such a cause of action might have with intellectual property, particularly copyright. The emerging tort is potentially a strong right in information. The appropriate parameters of protection of information are core to many aspects of copyright law. This article questions whether the sidelining of copyright law in the privacy debate is appropriate. In general there is an overlap between intellectual property, particularly copyright and privacy in relation to information. Specifically an overlap arises because there is a section in the Copyright Act 1994 that provides a privacy right in relation to films and photographs. This article examines that provision and concludes that in its current form it is inconsistent with the emerging tort of privacy in wrongful disclosure of private information.

\section{INTRODUCTION}

Reading the judgment of the Court of Appeal in Hosking $v$ Runting a lawyer without intellectual property experience could be forgiven for thinking that there is no connection between intellectual property law and the evolving tort of privacy. ${ }^{1}$ Such a lawyer would be wrong as not only is there a connection, but also the law of intellectual property, particularly copyright, could be usefully used to inform the modern privacy debate. ${ }^{2}$ In this context I refer to privacy in disclosure of personal information, rather than the line of privacy cases that relate to physical intrusion. Although I note that sometimes an intrusion can lead to information being obtained.

* Associate Professor of Law, Victoria University of Wellington.

$1 \quad$ Hosking $v$ Runting [2005] 1 NZLR 1 (CA).

2 For a general discussion of privacy see Raymont Wacks Personal Information: Privacy and the Law (Clarendon Press, Oxford, 1989). For a recent discussion of developments see G Phillipson "Transforming Breach of Confidence? To a Common Law Right of Privacy Under the Human Rights Act" (2003) 63 MLR 726; and M Richardson "Privacy and Precedent: The Court of Appeal's Decision in Hosking v Runting" (2005) 11 NZBLQ 82 
A central issue relating to the development of privacy as a tort is that too strong a privacy right gives a plaintiff something close in strength to a property right, which could be used to defeat freedom of expression. The balance between protection of information and freedom of expression is by no means an exclusive concern of privacy. Many aspects of the law of intellectual property balance the rights of intellectual property owners in the products of creative, scientific and business endeavours with the free use of those products and the information they contain in others' expressions of creativity. This article focuses on privacy's relationship with copyright law, which includes a number of property and quasi-property rights. Courts considering copyright claims are often required to balance the extent to which copyright should restrict use of information. For example the debate over copyright's protection of databases is centred on how much property protection should be given in view of the fact that such protection can all too easily give property over the information contained in the database. ${ }^{3}$ Relevant to the privacy debate are both legal connections and factual similarities that can be traced between the evolving law of privacy and the comparatively developed law of intellectual property.

One legal connection is section 105 of the Copyright Act 1994, which gives a privacy right to the commissioner of a photograph or a film, where that commissioner is not the copyright owner of the photograph. None of the judges in Hosking $v$ Runting appear to have been aware of this part of copyright law. Keith $\mathrm{J}$ gives an otherwise apparently comprehensive list of the ways in which privacy is recognised in statute, but his judgment does not refer to the Copyright Act. ${ }^{4}$

Another connection between the areas exists as some breach of confidence cases have also been copyright cases. ${ }^{5}$ Some so-called privacy cases could also be copyright cases. A plaintiff may have the good fortune to be able to use copyright as the tool to enforce a claim to privacy, if the source of private information is in a copyright work, such as a letter or a photograph. If, for example, a famous person's family photos were stolen from that person's house and then printed in a newspaper, that famous person might very well be able to claim that the newspaper had infringed his or her copyright. ${ }^{6}$

Photographs and written material such as letters or memos may be the subject of either a privacy or a copyright action. The subject matter is relevant for different reasons in privacy than it is in copyright, but the relationship between the two is not disparate. The privacy concern is with control

3 For a discussion of the protection of databases and information in New Zealand see Susy Frankel and Geoff McLay Intellectual Property in New Zealand (LexisNexis Butterworths, Wellington, 2002) 624-635.

4 See discussion in Part V B The Provision is Hidden and Overlooked in Hosking v Runting.

5 See discussion in Part II Breach of Confidence and Copyright.

6 See for example The Lady Anne Tennant v Associated Newspapers [1979] FSR 298 (EWHC), where the plaintiff, a lady in waiting to Princess Margaret sued the defendant newspaper for infringement of her copyright in photographs that she had taken of the Princess in private. 
of the photographic image or the content of a letter revealing private information. Whereas copyright primarily concerns itself with who reaps the economic benefit of the creation of a copyright work.

A number of recent privacy cases, including Hosking $v$ Runting and in the United Kingdom Campbell $v$ MGN Ltd, ${ }^{7}$ and Douglas $v$ Hello! Ltd, ${ }^{8}$ have all concerned the alleged wrongful disclosure of personal information through the publication of photographs, and in Campbell the publication of photographs and accompanying commentary. None of the plaintiffs in these cases were in a position to rely on copyright law as a mechanism to protect their so-called privacy, because they had no copyright interest in the photographs at issue. Yet it is conceivable that a privacy plaintiff may be able to invoke copyright in some circumstances.

Copyright is a useful tool for the privacy litigant only if the person who complains of the invasion of privacy is also the owner of the copyright, which will often not be the case. The owner of copyright in a photograph is most often the person who takes the photograph. ${ }^{9}$ The usual photography-related privacy complaint is of another person taking and using a photograph of the complainant.

Copyright law has rules of ownership, which are based on the theory of creativity and the corelative reward of ownership. The Copyright Act deems the creator of a work to be the author and in that capacity the author is the copyright owner. ${ }^{10}$ This basic premise is varied to acknowledge commercial reality so that, for example, authorship and consequential ownership of a film vests in the producer. ${ }^{11}$ Thus, for the most part if a plaintiff's complaint is one of a so-called invasion of privacy the ability to add a cause of action in copyright will be fortuitous.

Ownership of copyright does not primarily concern itself with the contents of a literary work or a photograph, except in as far as the work must be original. ${ }^{12}$ The rules of ownership do not in any way take account of privacy interests in the content of a copyright work. However, copyright law is not entirely blind to privacy. In addition to the privacy right in certain photographs and films, ${ }^{13}$ the

7 Campbell v MGN Ltd [2004] 2 WLR 1232 (HL).

8 Douglas v Hello! Ltd [2005] EWCA 595

9 Copyright Act 1994, s 21(1).

10 Copyright Act 1994, ss 5 and 21.

11 Copyright Act 1994, s 5(2)(b) provides that the creator of a work (and thus the author) shall be "in the case of a ... film, the person by whom the arrangements necessary for the making of the film ... are undertaken."

12 Copyright Act 1994, s 14 requires a work must be original to be protected under the Act.

13 Copyright Act 1994, s 105. The same provision is found in the Copyright Designs and Patents Act 1988 (UK), s 85 . 
Copyright Act incorporates a right for a copyright owner to control when a work is made public or kept private. ${ }^{14}$

It is possible to overstate the relationship between privacy and copyright. In many ways the overlap of the two has played out in a random way. ${ }^{15}$ Intellectual property primarily focuses on economic control of intellectual property works and privacy is concerned with access to information that may be contained in intellectual property works. Thus, when aspects of the law of copyright has developed, say for example in databases, privacy interests do not determine the scope of copyright protection. The copyright question is often focused on what use third parties may make of the database information. ${ }^{16}$ This article does not seek to recommend amalgamation of the two areas in any way. Its theme is to show the overlap between the two areas, with a particular focus on the privacy provisions in the Copyright Act 1994, and to comment on how copyright law can usefully be used in the debate about the emerging tort of privacy. In order to provide the necessary background, the longstanding relationship between copyright and breach of confidence is summarised in Part II. Part III discusses the protection that copyright law gives photographs. Stills from films can be used in the media in much the same way as a photograph and Part III of this article also analyses the protection that copyright law gives stills and how that differs from photographic copyright. Part IV analyses the relationship between privacy and copyright. In particular, it considers the right to keep unpublished works unpublished and the privacy provisions in section 105 of the Copyright Act in relation to photographs and films. It concludes that the Copyright Act's privacy provision does not provide a greater privacy right to information than the evolving tort. Finally, the article offers some concluding thoughts regarding the role that copyright law can play in informing the privacy debate.

\section{BREACH OF CONFIDENCE AND COPYRIGHT}

\section{A An Illustrative Sample of Cases}

Breach of confidence and copyright have a longstanding relationship. Many breach of confidence cases have also involved copyright claims. In Prince Albert $v$ Strange members of the royal family successfully claimed a kind of breach of confidence in relation to some family etchings, which the defendant sought to exhibit and publish. ${ }^{17}$ Lord Cottenham LC primarily

14 This is known as the right to issue to the public: Copyright Act 1994, ss 16(b) and 31.

15 Lee A Bygrave "The Technologisation of Copyright: Implications for Privacy and Related Interest" (2002) 24 EIPR 51, 51-52.

16 See for example Waterlow Directories Ltd v Reed Information Services Ltd [1993] ECC 174; [1992] FSR 409; Feist Publications v Rural Telephone Service Co (1991) 499 US 340; Tele-Direct (Publications) Inc $v$ American Business Information Inc (1997) 221 NR 113; 154 DLR (4th) 328 (FC); and Telecom v Colour Pages (14 August 1997) HC WN CP 142/97.

17 Prince Albert v Strange (1849) 1 Mac \& G 25; 41 ER 1171. 
reasoned that the author of works of art and literature had a right to keep those works unpublished. ${ }^{18}$ The distinction between breach of confidence and copyright was not made in the case, such a distinction not readily existing in law at the time. Lord Cottenham LC stated: ${ }^{19}$

The property of an author or composer of any work, whether of literature, art, or science, in such work unpublished and kept for his private use or pleasure, cannot be disputed.

The unauthorised revelation of unpublished copyright works has been treated as both infringement of copyright and breach of confidence in a number of cases. In Beloff v Pressdram the breach of confidence involved release of a journalist's memorandum that attracted copyright. ${ }^{20}$ The plaintiff was a journalist for the Observer newspaper and a Private Eye reporter reprinted a memorandum the plaintiff had allegedly written. The plaintiff was unable to conclusively prove copyright ownership so she was not successful, despite findings in her favour on the remaining aspects of copyright and breach of confidence.

In Hubbard $v$ Vosper the plaintiff, the founder of the Church of Scientology, tried to prevent a former scientologist from revealing the church's so-called confidential doctrines, which the plaintiff argued also attracted copyright protection. ${ }^{21}$ The plaintiff was not successful because Megaw LJ held that there was an arguable defence to copyright infringement based on fair dealing for the purposes of criticism or review and an arguable defence to breach of confidence because of the nature of the subject matter.

A report that contained confidential information that certain breathalyser tests were inaccurate was also the subject of a breach of confidence claim in Lion Laboratories $v$ Evans. ${ }^{22}$ The plaintiff further alleged that the publication of the information amounted to copyright infringement of a selection of documents. At first instance an injunction was granted but the Court of Appeal discharged the injunction except in respect of certain documents protected by copyright.

As well as the causes of action involving both breach of confidence and copyright all of the above cases considered whether the public interest in the information justified infringement of copyright or breach of confidence. In Hubbard v Vosper, for example, Megaw LJ reasoned that the public interest did not lie in protecting the alleged confidence or copyright because the subject

18 This was a common law right rather than a statutory right at the time of the case. The concept later became part of the statutory rights of copyright.

19 Prince Albert v Strange, above n 17, 1178.

20 Beloff v Pressdram [1973] 1 All ER 241 (Ch).

21 Hubbard v Vosper [1972] 2 QB 84 (CA).

22 Lion Laboratories v Evans [1984] 2 All ER 417 (CA). Also see Interfirm Comparison v Law Society of New South Wales [1977] RPC 137 Bowen J (SCNSW), which involved confidential information in a written document concerning business comparisons costs, productivity and related material. 
matter of the confidence and copyright were not matters that a court ought to condone the secrecy of, and in fact, may have been matters that the public had an interest in being exposed to. Therefore, His Honour concluded that there was no breach of confidence or infringement of copyright. ${ }^{23}$

\section{B Public Interest and Confidence}

The issue that has been central to breach of confidence cases and related claims of infringement of copyright is whether either is justified on the basis of public interest. An important distinction is between what is more akin to tabloid curiosity that is "interesting to the public" and matters of more genuine public interest. McMullin $\mathrm{J}$ in Spycatcher adopted the principle elucidated in Gartside $v$ Outram, ${ }^{24}$ that there can be no confidence in the disclosure of iniquity. ${ }^{25}$ In that case the "iniquity" related to the activities of the British Secret service. Although in the New Zealand chapter of the worldwide Spycatcher litigation the defence of public interest for exposing the iniquity was less central to the case than the issue of whether the confidence had been so widely exposed that an injunction was no longer appropriate.

An important issue in cases such as Hubbard v Vosper and Lion Laboratories $v$ Evans was the distinction between public interest and public curiosity. More recently the focus of breach of confidence cases, especially in the United Kingdom, has shifted to the public interest in not unduly restricting the right of freedom of expression, particularly the press's right to freedom of expression.

Whether the public interest defence, to breach of confidence and copyright infringement, is framed as exposing iniquity or allowing freedom of expression the defence has limits. Iniquity or freedom of expression may justify the breach of confidence because exposure of the confidential information is in the public interest, but the means by which that breach occurs may not justify an infringement of copyright if it is possible to expose the information without infringing copyright. So, for example, a wholesale reproduction of a copyright work, such as a letter or photograph, may not be required in order to reveal the confidential information contained in that letter. ${ }^{26}$

23 Hubbard v Vosper, above n 21, 95-96 Megaw LJ.

24 Gartside v Outram (1856) 26 LJ Ch 113, 114 Wood VC.

copyright cases the necessity or otherwise to reproduce the whole or large portions of a work for the purposes of fair dealing or permitted uses will often be at issue. For example, the reporting of current events, criticism or review which may be grounds to infringe copyright might not require actual reproductions of the copyright work that amounts to infringement. It might only require reporting the information. Although sometimes actual reproduction might be a justifiable means of authenticating the source: Pro-Seiban Media AG v Carlton UK Television Ltd [1999] 1 WLR 605 (CA) and Fraser-Woodward Ltd v British Broadcasting Corporation [2005] EMLR 22 (Ch). 
Ashdown $v$ Telegraph Group Ltd provides an example. ${ }^{27}$ In that case the copyright work at issue was a minute written by the then Liberal Democrat leader Paddy Ashdown. The minute recorded a meeting between a group of five politicians including Ashdown and the Rt Hon Tony Blair, the British Prime Minister. The minute recorded Tony Blair's alleged plan to assist the Liberal Democrats to win a by-election and his intention to form a coalition with the Liberal Democrats. This contradicted Tony Blair's public statements about his coalition plans. The Court of Appeal considered that there was public interest in the information and also held that, when assessing statutory fair dealing defences to copyright law, freedom of expression was relevant. ${ }^{28}$ There was no dispute that copyright existed, was owned by the plaintiff and had been infringed. The central issue was whether the use was fair and therefore a permitted use for the reporting of current events or criticism or review, under the copyright statute. ${ }^{29}$ On the facts there was public interest in revealing the minute's content, but the Court held that public interest and freedom of expression did not necessitate the verbatim reproduction of large portions of the minute. ${ }^{30}$

\section{Freedom of Expression and Privacy}

The statutory right of freedom of expression in New Zealand and United Kingdom case law is a more recent development than the doctrine of breach of confidence, although, the importance of freedom of expression and the media has been a theme during the development of the doctrine of breach of confidence. In New Zealand the right arises from section 14 of the New Zealand Bill of Rights Act 1990 (BORA) and in the United Kingdom from its signing of the European Convention on Human Rights. ${ }^{31}$ The development of the discussion of freedom of expression has subsequently been joined by the development of the discussion of a right to privacy.

There is a public interest in upholding the right of freedom of expression but, as with all rights, it is not unlimited. Freedom of expression is to be balanced against competing rights. ${ }^{32}$ Here the competing right is the right of privacy. As regards a right of privacy, the New Zealand and United

27 Ashdown v Telegraph Group Ltd [2001] 4 All ER 666 (CA).

28 Ashdown v Telegraph Group Ltd, above n 27, paras 24-35 Lord Phillips MR for the Court.

29 In New Zealand the equivalent permitted uses of copyright are found in the Copyright Act 1994, s 42.

30 Ashdown v Telegraph Group Ltd, above n 27, paras 45-46 Lord Phillips MR for the Court.

31 This Convention was incorporated into United Kingdom law by way of the Human Rights Act 1998.

32 For the method of balancing freedom of expression against competing rights see Moonen $v$ Film and Literature Board of Review [2002] 2 NZLR 754 (CA). 
Kingdom positions are somewhat different. In the European Convention there is a right of privacy, ${ }^{33}$ but in the BORA there is not. ${ }^{34}$

The two leading United Kingdom authorities on the right to privacy from disclosure of personal information are Campbell v MGN Ltd and Douglas v Hello! Ltd. ${ }^{35}$ In Campbell v MGN Naomi Campbell (the super-model) claimed that photos of her, which were combined with a description of her leaving a Narcotics Anonymous meeting, were an invasion of her privacy. The House of Lords held that the freedom of expression and privacy articles in the European Convention on Human Rights were applicable in disputes between individuals, and between individuals and nongovernment bodies such as newspapers. In Douglas $v$ Hello! the movie stars Michael Douglas and Catherine Zeta-Jones claimed Hello! magazine had invaded their privacy. The magazine had obtained photographs that had been surreptiously taken of the couple's private wedding. The Court of Appeal in Douglas v Hello! followed the European Court of Human Rights jurisprudence and held that it was obliged to ensure the protection of privacy in the United Kingdom, as required by the European Convention on Human Rights. ${ }^{36}$ The Court held that it needed to use the doctrine of breach of confidence to protect the privacy interest at issue. Lord Phillips MR noted "we cannot pretend to find it satisfactory to shoe-horn within the cause of action of breach of confidence claims for publication of unauthorised photographs of a private occasion". ${ }^{37}$ In Campbell $v$ MGN Lord Nicholls encapsulated the awkwardness of fitting cases involving private personal information under the confidence rubric. He stated: ${ }^{38}$

Now the law imposes a "duty of confidence" whenever a person receives information he knows or ought to know is fairly and reasonably to be regarded as confidential. Even this formulation is awkward. The continuing use of the phrase "duty of confidence" and the description of the information as "confidential" is not altogether comfortable. Information about an individual's private life would not, in ordinary usage, be called "confidential". The more natural description today is that such information is private.

33 Article 8(1) provides "Everyone has the right to respect for his private and family life, his home and his correspondence."

34 This is explained in Hosking $v$ Runting, above $\mathrm{n} 1$, para 181 Keith $\mathrm{J}$.

35 Campbell v MGN Ltd, above n 7; Douglas v Hello! Ltd, above n 8.

36 The Court referred to von Hannover v Germany [2004] ECHR 294 where the European Court of Human Rights held on the basis of article 8 that certain press photographs taken in public infringed Princess Caroline of Monaco's privacy rights: cited in Douglas $v$ Hello! Ltd, above n 8, paras 47-49 Lord Phillips MR for the Court.

37 Douglas v Hello! Ltd, above n 8, para 53, Lord Phillips MR for the Court.

38 Campbell $v$ MGN Ltd, above n 7, para 14 Lord Nicholls. 
Despite judicial concerns about the uncomfortable usage of breach of confidence to accommodate actions for privacy the United Kingdom Courts have used the doctrine to capture misuse of private information. "Awkwardness" of the fit aside, the use of breach of confidence has a potential benefit, as yet unexplored in the new privacy context. That is that, there is a more direct link to intellectual property law.

\section{Hosking v Runting}

In New Zealand the most authorative discussion of the right to privacy, referred to as a tort rather than a right, is Hosking $v$ Runting. The majority of the Court of Appeal concluded that there was a limited tort of wrongful publication of private information, ${ }^{39}$ but not a right to private life in all circumstances. ${ }^{40}$ On the facts the limited privacy right was not made out, but the majority of the Court held that it existed and could be successfully harnessed with appropriate facts. The Hoskings' claim was not successful because not only were the photographs in dispute taken in a public place, but also the publication of the photographs did not convey any private information. Gault $\mathrm{P}$ and Blanchard J expressly chose not to develop the doctrine of breach of confidence to accommodate actions for wrongful publication of private matters. In part this was not only because of the view that it would muddy the existing doctrine, but also previous case law had strictly adhered to the requirements of breach of confidence that the information must be conveyed in a confidential situation. ${ }^{41}$ Gault $\mathrm{P}$ and Blanchard $\mathrm{J}$ (in a joint judgment) and Keith $\mathrm{J}$ (in a dissenting judgment) reasoned that the development of the law of confidence was possible in the United Kingdom because there has not been the same adherence to the requirement that the information be imparted in circumstances of confidence as there has been in New Zealand. ${ }^{42}$

Although the doctrinal approaches to privacy cases may differ in New Zealand and the United Kingdom, recent cases in both jurisdictions have concerned the use of photographs of well-known celebrities or their relatives. The next section discusses photographs as copyright works and the privacy interests in such photographs.

\section{PHOTOGRAPHS AND COPYRIGHT}

\section{A The General Protection of Photographs as Copyright Works}

Despite the power of the image, copyright has not always protected photographs. Initially copyright law treated photographs as being merely mechanical reproductions of scenes rather than creative works in their own right. This rather limited view of the art of photography was gradually

\footnotetext{
39 Keith J and Anderson J dissenting on this point.

40 Hosking $v$ Runting, above $\mathrm{n}$ 1, para 117 Gault $\mathrm{P}$ and Blanchard J, para 259 Tipping J.

41 Hosking v Runting, above $\mathrm{n}$ 1, paras 45-53 Gault P and Blanchard J.

42 Hosking $v$ Runting, above n 1, paras 45-53 Gault P and Blanchard J, paras 200-201 Keith J.
} 
eroded over the $19^{\text {th }}$ and $20^{\text {th }}$ centuries giving rise to protection of photographs as artistic works under copyright law in many jurisdictions. ${ }^{43}$ As a category of artistic work under New Zealand and United Kingdom law the photograph is protected regardless of its artistic quality; ${ }^{44}$ although, a photograph will still have to reach the requisite threshold of originality in order to qualify for copyright protection. ${ }^{45}$ Any copyright in the photograph initially vests in the author of the photograph. ${ }^{46}$ If a photograph is commissioned initial ownership of the copyright will vest in the person commissioning the photograph. ${ }^{47}$ Many contracts with photographers include a clause that reverses the commissioning ownership situation. Thus, when a person commissions family photographs it is unlikely that person will own the copyright because the contract with the photographer will assign the copyright back to the photographer. The rationale for this practice is that otherwise the photographer's livelihood is in jeopardy, because without the benefit of copyright there would be no basis on which the photographer could charge a sum for prints. ${ }^{48}$

The media uses photographs and stills from films. In practice the distinction between the two is only relevant to copyright law. ${ }^{49}$ To the public the reprint of a photograph or a still from a film will likely not appear to be any different, however, a still from a film is not, for copyright purposes, the same as a photograph. This next section considers the protection of stills from films and its nexus with privacy.

43 For a discussion of copyright protection of photographs as artistic works see C Swan "Photography and the Copyright Act" (1990) 8 Int'l Media L 5. For a discussion relating to ownership of copyright in photographs see Ysolde Gendreau "Copyright Ownership of Photographs in Anglo-American Law" (1993) 15 EIPR 207.

44 Copyright Act 1994, s 2 definition of "artistic work"; Copyright Designs and Patent Act 1988 (UK), s $4(1)(a)$

45 Copyright Act 1994, s 14.

46 Copyright Act 1994, ss 5 and 21(1).

47 Copyright Act 1994, s 21(3).

48 Copyright law reform has from time to time had to consider whether journalists or their employers own copyright in photographs. The journalist's exception under section 4(2) of the Copyright Act 1956 (UK) and section 5(b) of the Copyright Act 1911 (UK) provided that, where in the course of employment at a newspaper or the like, an author created a literary, dramatic or artistic work the employer only owned copyright in the work as it related to the publication of the work in the newspaper. Any other aspects of copyright belonged to the employee.

49 Copyright Act 1994, s 2 defines photograph as "a recording of light or other radiation on any medium on which any image is produced or from which an image may by any means be produced, but does not include a film or part of a film". 


\section{B Copyright and Stills from Film}

Copyright law treats the still as part of a film. Even though it is only part of a film use, of one still can amount to infringement of the film on the basis that it is infringement of the film as a whole. ${ }^{50}$

Hyde Park v Yelland involved use of images of Princess Diana and Dodi Al Fayed taken from a security camera film. ${ }^{51}$ The stills featured in The Sun tabloid alongside much larger, clearer and glossier photographs of Princess Diana and Dodi Al Fayed on a summer holiday. The security camera was the property of Dodi's father Mohammad Al Fayed. The stills in question showed the Princess arriving at the Villa Windsor in Paris (the former home of Edward VIII and Mrs Simpson) at a particular time and leaving approximately one half hour later. Apart from the fame of the people depicted in the stills, the "newsworthiness" was that the stills contradicted Mohammad Al Fayed's story that the couple visited the villa for a lengthy time to discuss redecorating details because they planned to reside there together. Mohammad Al Fayed's story was part of his ongoing campaign to convince the British public that his late son and the late Princess had planned to marry. Mohammad Al Fayed was the owner of the copyright in the stills as they were taken with his security camera. He brought proceedings against The Sun for infringement of copyright. There was no dispute over the subsistence of copyright or its prima facie infringement. The central issue was whether The Sun's use of the stills was a permitted use under the fair dealing defence of reporting of current events. The copyright infringement claim was not successful.

It is unclear whether the result would be the same in New Zealand if facts analogous to those in Hyde Park $v$ Yelland arose here. Under United Kingdom law a film does not have to be original to attract copyright. ${ }^{52}$ If this or a similar case had occurred in New Zealand the result may have been different because the film may not have qualified for copyright protection in the first place. Under New Zealand law the film has to be original to attract copyright. ${ }^{53}$ The rationale of the New Zealand Copyright Act 1994 for requiring originality in regard to films is not clear. ${ }^{54}$ In a case such as Hyde Park it would likely be an issue whether such a film was an original work. A plaintiff could argue that the placing of the video camera and possibly even its operation involved skill, judgment and labour. These are the hallmarks of the test of originality for the subsistence of copyright. ${ }^{55}$ The

50 Copyright Act 1994, s 2 definition of "copying" includes "the making of a photograph of the whole or any substantial part of any image forming part of the film ...".

51 Hyde Park $v$ Yelland [2001] 2 Ch 143 (CA).

52 Copyright, Designs and Patents Act 1988 (UK), s 1(1)(b)

53 Copyright Act 1994, s 14

54 See discussion in Frankel and McLay, above n 3, 5.6.1.

55 Frankel and McLay, above n 3, 5.6. 
counter-argument would be that these skills alone are not enough because if they were it would allow a very low threshold of originality. But that New Zealand has a low threshold of originality is supported in case law in general. ${ }^{56}$ On the other hand, perhaps the requirement of originality in relation to film has the unintentional effect of making such mundane creations not the subject of copyright. That would appear not to have been Parliament's intention because such a radical departure from the previous Copyright Act 1956 and the United Kingdom law goes undocumented in Select Committee considerations and Hansard. ${ }^{57}$ The practical effect is that a plaintiff seeking to prevent publication of security camera film under New Zealand copyright law would need to prove that the film amounted to an original copyright work in the first instance. A security camera film may not reach the requisite originality threshold, but each case must be assessed on its facts.

\section{Public interest in infringing copyright}

The Sun's defence of reporting current events required an assessment of whether the publication of the stills was really an event of public interest. The Copyright, Designs and Patents Act 1988 retained a provision preserving any rule of law "preventing or restricting the enforcement of copyright on the grounds of public interest". ${ }^{58}$ The same provision is in New Zealand's Copyright Act $1994 .{ }^{59} \mathrm{Jacob} \mathrm{J}$ (as he then was), in the High Court, considered that the public interest defence was an additional defence to copyright infringement. His Honour reached this conclusion in part because of concern to maintain freedom of expression. In doing so His Honour rejected the argument that copyright embodies the appropriate balance between property and freedom of expression, ${ }^{60}$ and stated that public interest could be invoked as a defence in certain circumstances. ${ }^{61}$ Such recognition that upholding the right of freedom expression in the copyright context is in the public interest was knocked back in the Court of Appeal. There, Aldous LJ prescribed tight rules for the defence's application. ${ }^{62}$ Mance LJ preferred not to determine

56 Frankel and McLay above n 3, 5.6.4.

57 Frankel and McLay, above n 3, 5.7.

58 Copyright, Designs and Patents Act 1988 (UK), s 171(3).

59 Copyright Act 1994, s 225(3).

60 Blanchard J held that this was the situation in New Zealand in Television New Zealand $v$ Newsmonitor Services [1994] 2 NZLR 91 (HC). See generally Yvonne Cripps The Legal Implications of Disclosure in the Public Interest (2 ed, Sweet \& Maxwell, London, 1994); Jo Oliver "Copyright, Fair Dealing and Freedom of Expression" (2000) 19 NZULR 89.

61 Over and above a ground not to provide interlocutory relief.

62 Hyde Park v Yelland, above n 51, 160 Aldous LJ. 
conclusively the situations in which it could be invoked. ${ }^{63}$ Mance LJ's approach was later preferred in Ashdown, where Lord Phillips MR stated: ${ }^{64}$

Now that the Human Rights Act is in force there is the clearest public interest in giving effect to the right of freedom of expression in those rare cases where this right trumps the rights conferred by the Copyright Act.

\section{The strength of copyright and apparent strength of privacy}

Copyright is a strong property right and extremely useful weapon and thus all the more fortuitous if available to a "privacy" plaintiff. Its strength is visible in the above quotation, that it would be rare that freedom of expression would trump copyright. Although, Mohammed Al Fayed was not successful in his copyright claim, a clear infringement of copyright was established in Mail Newspapers $v$ Express Newspapers. ${ }^{65}$ This dispute concerned the publication of wedding photos of a couple whose newsworthiness related to the woman being in a coma while pregnant and being kept "alive" in order to save the unborn baby. The couple's celebrity status was brief rather than long term. The husband depicted in the wedding photographs sold the rights to print the photographs to the plaintiff newspaper, which brought proceedings to stop the defendant newspaper from printing the same photographs. There was no dispute that copyright had been infringed. The defendant contested the plaintiff's ownership of the copyright, but an injunction was granted.

In contrast, a plaintiff relying on a right of privacy theoretically has two equal, but competing human rights to balance on the facts. However, the right of privacy of the type extended to Campbell, Douglas and Zeta-Jones, all but gave them an exclusive right to control their personal information. The privacy right is almost as strong as the property right. It falls short of being a property right because it is personal and presumably not assignable. Protection of information to this extent is arguably such a strong right that it makes it harder for freedom of expression to prevail. The strength of this privacy right is perhaps ironically illustrated by a comparison of the cases discussed here. The only privacy claimant, discussed above, with a "true" property right of copyright, was Mohammed Al Fayed who lost his case; whereas Campbell and Douglas and ZetaJones won theirs.

63 Hyde Park $v$ Yelland, above n 51, 172 Mance LJ. 


\section{Ownership of Copyright}

Copyright will initially vest in the person who creates the copyright work. ${ }^{66}$ This is an important part of copyright law because the basic justification behind the law of copyright is that it protects creative endeavours and rewards creators with copyright ownership. ${ }^{67}$ Copyright law utilises contract to change initial ownership and to have exceptions to the basic rule that the creator of the work is the copyright owner. It would, however, be inappropriate to give any property rights to the person or persons captured in the image of a photograph or film because they have not invested copyright-defined originality in making the photograph. A comparison can be drawn to how copyright law treats an actor in a play. It would be inappropriate to give an actor ownership over the copyright in the play, even though the actor may give a very creative performance. Although an actor as a creative contributor may find him or herself in a better position that the mere subject of a photograph because the actor may have performers' rights associated with his or her creative performance.

The subjects of the photographs in the confidence/privacy cases do not usually add creative input to the particular photographs in dispute. It is possible to conceive of situations where the subject of a photograph makes a creative contribution, such as artistically directed photography. perhaps even the kind that a supermodel appears in. But this level of creativity does not usually achieve performers' rights or the equivalent and is not recognised as a copyright right, a performer's right or a property or quasi-property right of any kind under United Kingdom or New Zealand copyright law.

Occasionally, the person seeking privacy might own copyright in the photographs at issue if that person took the photographs, say of their family. But copyright in paparazzi-style photographs or film taken surreptitiously in a public or not such a public place will not be owned by the subject of the photograph or film. The subject of the photograph does not, outside of some parts of the United States, have property rights in his or her image in the photograph or film. ${ }^{68}$

Campbell, Douglas and Zeta-Jones could not utilise copyright law in their quest for privacy. They were not the owners of the covertly taken photographs, but were merely depicted in them. In Campbell $v M G N$ the photographs at issue were covertly taken in a public place. It was not the covert taking of the photographs that was the complaint, but that the accompanying text and the photographs together conveyed private information. In Douglas $v$ Hello! the photographs were

66 Copyright Act 1994, s 21(1). This is the first rule. The author is defined in relation to certain types of work and that person is not necessarily the only creator. For example the author and first owner of a copyright in a film is the producer: Copyright Act 1994, s 5(2)(b).

67 See generally B Sherman and L Bently The Making of Modern Intellectual Property Law (Cambridge University Press, Cambridge, 1999).

68 See generally Oliver R Goodenough "Retheorising Privacy and Publicity" (1997) 1 IPQ 37. 
covertly taken but they were not taken in a public place. Douglas and Zeta-Jones's complaint was also that the photographs contained private information because they were of a private occasion.

\section{PRIVACY AND COPYRIGHT LAW}

The person who seeks to restrain a breach of confidence or claim a right of privacy in relation to photographs or stills is unlikely to be able to invoke copyright law except in rare circumstances, of ownership, discussed above. Copyright claims of plaintiffs in relation to literary works are conceptually more likely because the plaintiff, like Paddy Ashdown, is more like to be the owner of the literary work. Copyright law, however, has other aspects that involve privacy concerns. A work can attract copyright whether it is published or not. ${ }^{69}$ The right of an owner of a copyright work to prevent others from first publishing that work in part recognises that unpublished works may be private until the owners decide otherwise. Section 105 of the Copyright Act 1994 also contains an express provision that recognises privacy interests in some photographs and film in some circumstances. Each of these is discussed in this part.

\section{A Unpublished Works}

Until the most recent copyright laws, copyright made a number of distinctions based on whether works were published or unpublished. ${ }^{70}$ Under the Copyright Act 1994 copyright vests in both published and unpublished works. The owner of copyright in any work has the right to stop that work being issued to the public. ${ }^{71}$ Broadly speaking this is a right of first publication, which may be in the nature of a right of first sale. Once a work is published it cannot be regarded as private and copyright law expressly reserves the choice of publication to the copyright owner, in the form of the right to issue a copyright work to the public.

The rationale behind the right to issue to the public is to ensure that the copyright owner has the ability to seek the maximum economic reward from first publication. It is probable that the economic rationale is the main basis behind the right to issue to the public and the privacy rationale is an important, but incidental by-product of the economics that drive copyright law.

\section{B Privacy of Films and Photographs}

New Zealand's Copyright Act 1994 includes an isolated recognition of privacy rights of individuals in films and photographs in some limited circumstances. Section 105 appears in the part of the Act that sets out moral rights, but it is not what copyright internationally recognises as moral

69 Copyright Act 1994, s 14 makes no distinction between published and unpublished works.

70 See Copyright Act 1956 (repealed).

71 Copyright Act 1994, s 16, and definition of "issue to the public" in s 8. 
rights; which are primarily the rights to object to derogatory treatment of a work and to claim authorship. ${ }^{72}$ Section 105 of the Copyright Act 1994 provides:

Right to privacy of certain photographs and films-

(1) A person who, for private and domestic purposes, commissions the taking of a photograph or the making of a film has, where copyright exists in the resulting work but is owned by some other person, the right -

(a) Not to have copies of the work issued to the public; and

(b) Not to have the work exhibited or shown in public; and

(c) Not to have the work broadcast or included in a cable programme.

Subsections (1)(a), (b) and (c) give the person commissioning the photograph or film some of the copyright rights that an owner of copyright would otherwise have. ${ }^{73}$ Notably, however, the rights are all modes of publicity of one sort or another. The fundamental economic right to copy the photograph or film remains the owner's right.

There are several points to note about this section. A person can only invoke the section if they are not the owner of copyright in the photograph or film. ${ }^{74}$ The person must have commissioned the photograph or film for private and domestic purposes. The section does not require that the person be the subject of the film or photograph and, thus, gives a commissioner a privacy right in relation to photographs of any subject matter, provided that they were taken for private or domestic purposes. This is a rather different privacy right than that relating to wrongful disclosure of private information which ought to identify the person who claims the privacy right. ${ }^{75}$

The section appears to benefit those who hire photographers for family photos, wedding videos and the like. But close scrutiny reveals that the section is almost superfluous. A person who commissions the taking of a photograph or film is the first owner of copyright in the photograph or film. ${ }^{76}$ Section 105 adds no extra rights to those that the commissioner would have as the initial copyright owner. But, in any event, the section only applies if the commissioner is not the owner.

72 Berne Convention for the Protection of Literary and Artistic Works (9 September 1886) as revised at Paris (24 July 1971) 1161 UNTS 30, art 6bis.

73 Copyright Act 1994, s 16.

74 Photograph is defined as "a recording of light or other radiation on any medium on which an image is produced or from which an image may by any means be produced: but does not include a film or part of a film". Film is defined as "a recording on any medium from which a moving image may be produced", Copyright Act 1994, s 2.

75 Katrine Evans "Of Privacy and Prostitutes" (2002) 20 NZULR 71.

Copyright Act 1994, s 21(3). 
The salient difference in the equivalent United Kingdom law is that it does not have the provision that the commissioner of a photograph or film is the first owner of copyright. ${ }^{77}$

Bearing in mind that in New Zealand a private and domestic commissioner might assign the copyright to the photographer or filmmaker, one possibility is that section 105 gives the privacy right where the commissioner is no longer the owner of copyright. But, even in that situation it remains questionable whether the section is necessary to achieve its stated goal of privacy.

\section{The Privacy Act 1993 and commissioned photographs and films}

The Privacy Act 1993 may in a limited way protect the commissioner of the photograph or film. The news media is not caught under the Privacy Act. ${ }^{78}$ This seems to mean that activities of the paparazzi are not subject to the Privacy Act, but this might not mean that all photographic material the media uses is devoid of protection under the Privacy Act. The photographer or filmmaker commissioned on a private basis, who is not primarily involved in these activities for the media, could be described as collecting personal information. ${ }^{79}$ That personal information in the form of photographs or film was "collected" for the purpose of selling the resulting photographs or films to the commissioner and unless otherwise agreed the photographer cannot use that information for another purpose. ${ }^{80}$

The exclusive rights that section 105 gives to the commissioner are stronger than those in the Privacy Act, which are generally not enforceable before a court. ${ }^{81}$ But the Privacy Act achieves a certain level of privacy. That being so, why should the Copyright Act 1994 give this elevated privacy protection only to those photographs and films of a private and domestic nature that were commissioned? Copyright is dipping its toes in the water and providing a very limited privacy right. If other law provides a greater or lesser privacy right, which in New Zealand has not been conclusively decided, then it is not the business of copyright law to distinguish between different sorts of privacy protection. The following sub-sections examine whether the catchment of section 105 is justifiable.

77 The commissioning provision in the Copyright Act 1956 (UK) was not repeated in the Copyright, Designs and Patents Act 1988 (UK) and, thus, the privacy provision, section 85, was enacted. For a pre-1988 Act case see Mail Newspapers v Express Newspapers, above n 65.

78 Privacy Act 1993, s 56. See Crimes (Intimate Covert Filming) Amendment Bill 2005, no 257-2, which will make it an offence including for the news media, to surreptitiously film intimate situations involving nudity, partial nudity, or sexual or other intimacy where people would have a reasonable expectation of privacy.

79 Privacy Act 1993, s 2.

80 Privacy Act 1993, s 6, Information Privacy Principle 10.

81 Privacy Act 1993, s 11(2). 


\section{Should section 105 apply to other types of copyright works?}

The provision is arguably unjustifiably narrow in the types of copyright works singled out for protection. Why should commissioners of literary works not acquire such a right? Commissioners of literary works do not enjoy first ownership rights like commissioners of films and photographs. ${ }^{82}$ If I commission a person to write my biography that person may very well record much private and very personal information. Of course, we may sign a contract of confidence, but this does not distinguish the situation from that of the photographer or filmmaker. The only distinction might be that commissioning photographs is something many people do, but a biography is a comparatively rare event. This distinction only takes the matter so far. Copyright is not primarily a consumer protection law. The justifications for copyright are to protect the economic interests of copyright owners and to encourage the creation of copyright works. ${ }^{83}$ No reason can be derived from these justifications for carving out only commissioned photographs and films for privacy protection. Further, the absence of a direct link between the rationales of copyright and the privacy goal supports the argument that section 105 should not be in the Copyright Act 1994. This is discussed in Part V.

3 Should section 105 apply to non-commissioned photographs and films of private and domestic matters?

The narrow application of section 105 to commissioned photographs and films makes it an ineffective tool for the would-be privacy litigant whose is filmed or photographed surreptitiously. This is no doubt why in Douglas $v$ Hello! the plaintiffs could not invoke the United Kingdom privacy section against the photographer who intruded on their wedding. If a photographer invades the private and domestic realm, albeit of a rather grand celebrity wedding, the subject of the photographs might wish to control the publicity of the invader's photographs as much as any commissioned photographs. ${ }^{84}$ Indeed, this might in part be why the Court of Appeal was prepared to extend breach of confidence to Douglas and Zeta-Jones.

What then is the policy behind excluding the Douglas and Zeta-Jones type of scenario from the ambit of the copyright privacy provision? Why not extend it to capture the non-commissioned photographs taken in the private and domestic realm? The only reason seems to be that surreptitious photography and the use of long distance lens as a means of photographic invasion is not the usual stuff of the private and domestic realm, but is only directed at celebrities. If the Douglas v Hello facts arose in New Zealand the Court in Hosking $v$ Runting has made it clear that it would not extend breach of confidence in the way the United Kingdom Courts have, but it may meet the

82 Copyright Act 1994, s 21.

See generally, Frankel and McLay, above n 3, 5.1.

84 See also Shelly Films Ltd v Rex Features Ltd [1994] EMLR 134 and Creation Records Ltd v News Group Newspapers Ltd [1997] EMLR 444, which both involved surreptitious photography. 
criteria of Gault P and Blanchard J's tort of privacy. ${ }^{85}$ In which case it is odd that copyright law gives privacy to some potential invasions but not others. If section 105 is to remain in the Copyright Act 1994, there seems no basis for it to be any narrower or no greater than the privacy rights protected under a breach of confidence action or the developing tort.

Although the copyright ownership provisions might trigger the argument in favour of the existence of the rights in section 105, such rights should be consistent with the theories and justifications of privacy protection.

\section{SHOULD THE PRIVACY PROVISION BE IN THE COPYRIGHT ACT 1994 AT ALL?}

The provision addresses the potential unfairness that arises when the commissioner of private photographs or film is not the owner of copyright, and the photographer or filmmaker had made inappropriate use of the photographs or film. The photographer could, for example, display the commissioners' photograph for advertising purposes on the main street, or the filmmakers might include a few frames in a television advertisement. This possibility of mistreatment of consumers' images arises because of the ownership of copyright. The connection with copyright ownership suggests that the section is well placed in the Copyright Act 1994. This part examines whether that is in fact so.

\section{A Does the Expanding Nature of Copyright Justify its Expansion into Privacy?}

As a general principle the policy behind New Zealand's copyright law ought to be consistent, particularly as it expands in nature and scope, but often the expansion of copyright law is a response to the development of technology and the logical development of the underlying rationales for copyright protection is not clear. The expansion of copyright's reach in the digital era has invigorated the debate over the purpose of copyright.

Copyright has for the last 15 or so years been seen to expand in its ambit along with new technologies. For some years now New Zealand policymakers and academics have been assessing and debating how far copyright law should be extended in relation to digital material. ${ }^{86}$ The digital era has seen the development of the WIPO Copyright Treaty, ${ }^{87}$ which aims to extend the Berne

85 Hosking $v$ Runting, above n 1, para 117 sets out "two fundamental requirements for a successful claim for interference with privacy:

1 The existence of the facts in respect of which there is reasonable expectation of privacy; and

2 Publicity given to those private facts that would be considered highly offensive to an objective reasonable person".

86 See Ministry of Economic Development <http://www.med.govt.nz> (last accessed 13 September 2005) for discussion documents.

87 WIPO Copyright Treaty 1996, available at <http://www.wipo.org > (last accessed 13 September 2005). 
Convention copyright protection to the digital world. As a result a number of quasi-copyright rights have been added to copyright legislation in various jurisdictions. The inclusion of quasi-copyright provisions in copyright law is a phenomenon that also occurred prior to the digital era. The inclusion of performers' rights in the Copyright Act 1994 provides an example. European jurisdictions have always treated copyright in films, sound recordings, broadcasts and cable programmes to be "neighbouring rights" to the core of copyright: literary, dramatic musical and artistic works. Part of this caution is that although there may be a relationship between, say, performers rights and copyright, the former is not as strong a property right as the latter. Similar arguments can be made in relation to digital management rights. Such rights should arguably not be part of copyright law if one takes a "pure" approach to the justifications for copyright protection. Whether digital management rights and the like are true copyright rights is an issue beyond the scope of this article. Its relevance is that an analogous argument can be made in relation to privacy provisions in the copyright statutes. Utilising the exclusive rights of the copyright owner, as section 105 does, upgrades the privacy right to a property right, albeit limited to the three strands of issuing to the public, exhibiting to the public and including in a cable programme or broadcast. The privacy right may still entitle the privacy claimant to an injunction and damages, which although difficult to prove are not precluded. ${ }^{88}$

\section{B The Provision is Hidden and Overlooked in Hosking v Runting}

Section 105 is almost uncommented on in "privacy circles". It has not been the subject of much academic commentary and was overlooked in Hosking $v$ Runting.

In Hosking $v$ Runting Keith $\mathrm{J}$ joins with Gault $\mathrm{P}$ and Blanchard $\mathrm{J}$ in finding against the plaintiff's claim, but dissents where Gault $\mathrm{P}$ and Blanchard $\mathrm{J}$ were prepared to find a limited tort of privacy for wrongful disclosure of private information. ${ }^{89}$ Keith $\mathrm{J}$ concludes that there is no basis for formulating the tort. His Honour reached his conclusion because the law already expressly deals with privacy issues in a number of ways. This conclusion was supported by Keith $\mathrm{J}$ with reference to the New Zealand Bill of Rights Act 1990. ${ }^{90}$ In his judgment Keith J sets out the ways in which the law deals with privacy. Section 105 of the Copyright Act is omitted from an otherwise apparently comprehensive list. ${ }^{91}$ It is a somewhat glaring omission in view of the statement His Honour makes in relation to photographs taken by private investigators: ${ }^{92}$

88 Copyright Act 1994, s 125 and for a different approach under United Kingdom law, see W R Cornish "Moral Rights Under the 1988 Act" (1989) 11 EIPR 449, 452.

89 Hosking $v$ Runting, above $\mathrm{n} 1$, para 176 Keith $\mathrm{J}$.

Hosking $v$ Runting, above n 1, para 208 Keith J.

91 Hosking $v$ Runting, above n 1, para 185-199 Keith J.

92 Hosking $v$ Runting, above $\mathrm{n} 1$, para 188 Keith $\mathrm{J}$. 
And, coming closer to the facts, it is an offence for a private investigator to take photographs or make recordings of any person without their written consent [emphasis added].

The copyright provision is arguably as close, if not conceptually closer to the facts of Hosking. Not only because of the use of photographs, but because they were not commissioned and were taken by the media not private investigators. Although a person is unlikely to commission the media in a way that invokes section 105 the link to the media provides a link to the law of breach of confidence and the cases discussed above. Further, some of those cases also involve copyright claims. Spycatcher is an example. ${ }^{93}$

But it is not just the occasional factual association between breach of confidence and copyright that is important. The relationship between privacy concerns and intellectual property law as a whole was overlooked in Hosking $v$ Runting. In part, this may have been because of the decision not to develop the breach of confidence doctrine to arrive at a limited tort of privacy. But in Keith J's judgment the tort was not available for development in any event.

I note that including a discussion of how section 105 protects privacy would probably not have changed Keith J's conclusion. In fact, it may have bolstered it by the reasoning that Parliament had a specific opportunity to consider privacy and photographs and chose to limit it. This limitation may, however, arise simply because it is in the Copyright Act 1994. There is no evidence that Parliament when passing section 105 considered the whole range of potential privacy invasions using films and photographs.

\section{CONCLUDING THOUGHTS}

One of the difficulties of formulating rights to privacy is how strong the right should be. As a right it theoretically has less strength than a property right; the Privacy Act 1993 is generally unenforceable before a Court. ${ }^{94}$ But the equivalent right in wrongful disclosure of private information developed out of breach of confidence in the United Kingdom has all the enforceability of a quasi-property right in personal information, taking it well away from its origins. ${ }^{95}$

Intellectual property, particularly copyright, ought to be a consideration in the formulation of any tort of privacy relating to information; particularly, the limited right of disclosure of private information outlined in Gault P and Blanchard J's judgment in Hosking $v$ Runting. This comes close to giving a form of property right in private facts. To do this without an analysis of the parallel area of copyright is unfortunate for two reasons. First, copyright law abounds with the debate over protectable and unprotectable facts and the dangers of giving proprietary rights in information. Second, where copyright law dips its toes into privacy law the two areas should be consistent.

93 Attorney-General for UKv Wellington Newspapers Ltd, above $\mathrm{n} 25$.

94 Privacy Act 1993, s 11(2).

95 For a general discussion of the origins of breach of confidence see Frankel and McLay, above n 3, 10.4. 
Copyright law should not extend privacy beyond that which exists outside of the area of copyright because there is no rational basis for copyright to do so. Section 105 of the Copyright Act 1994 presently does just that. One alternative is to have no such privacy right in the Copyright Act 1994. This might mean that the unscrupulous photographer, provided he or she owned the copyright, could without consultation use a client's private photos to advertise the photographer's services. Assuming that such a possibility is undesirable then the remedy is easily dealt with under the same umbrella as copyright ownership. But this alone gives no satisfactory explanation why the copyright privacy right is limited to films and photographs and does not cover all copyright works, including literary works and other artistic works such as drawings. The limited sphere of the copyright privacy section to the commissioning of a film or photograph for private purposes, may have the advantage that it in no way encroaches into the murky area of celebrities and unauthorised images, but this distinction is not based on any particular rationale of copyright law and thus remains questionable.

The area of protection of a person's image is another area where the copyright and privacy nexus might be relevant should there be any future developments in the tort of privacy. This is especially so as control over one's image or a "publicity" type of right is an application of a so-called "privacy" right in the United States. ${ }^{96}$

It may be that the copyright analogy has its limits because the ambit of copyright's protection of information has an independent rationale, which does not prevent the so-called tort of privacy from developing, but that remains unexplored. Whether this is so might be the subject of another article.

96 For a general discussion see William Prosser "Privacy" (1960) 48 Cal L Rev 383; and Jonathan Kahn "Privacy as a Principle of Identity Maintenance" (2003) 33 Seton Hall LR 371. 